\title{
RHODESIA AND THE UNITED NATIONS: THE LAWFULNESS OF INTERNATIONAL CONCERN
}

\author{
By Mrres S. MICDougaL \\ Of the Board of Editors \\ AND \\ W. Mirohafi Reisman \\ Yale Law School
}

Locked in south central Africa by Zambia, Mozambique, Botswana and the Republic of South Africa, Rhodesia ${ }^{1}$ comprises a land mass of over 150,000 square miles and a population of about four million blacks and 220,000 whites. ${ }^{2}$ From 1889 until 1922 the area was administered by a chartered company formed by Ceeil Rhodes. ${ }^{3}$ In 1922 the white settlers opted for the status of a self-governing colony, and in 1923 Southern Rhodesia was annexed by Great Britain.4 In 1953 it joined, with Northern Rhodesia and Nyasaland in a federation, still under the United Kingdom $;^{8}$ the venture proved unsuccessful and was terminated in $1963 .^{\circ}$ Thereafter the goal of the white Rhodesians became that of political

1 The reference "Rhodesia" throughout this article is to Southern Rhodesia, the latter being, from the perspective of British constitutional law, the proper name for the area. We employ the short form for purposes of economy only.

2 For general statistics, see 1964-1965 Statesman's Year-Book 473-480 (1964). The area of Rhodesia comprises the Matabele Kingdom, Mashonaland and Manicaland: Palley, The Constitutional History and Law of Southern Rhodesia 1888-1965 xxiii (1966).

3 For the text of the Charter of the British South Africa Company, see C. 5918, Encl. at 227-232; and for critical commentary, see Palley, op. cit. note 2 above, at 33-43. For brief details of Rhodes' aequisition of power in the area, see Rogaly, Rhodesia: Britain's Deep South 9-12 (1962, The Economist Intelligence Unit).

4 Southern Rhodesia (Annexation) Order in Couneil 1923; the Constitution of 1923, described as a "typical 'Westminster export model'", by Palley, is found in S.R.\&O. Rerised xxi at 371. An examination of the Constitution and its history of application indicates that the contention that Rhodesia has been completely selfgoverning for 40 Jears is without factual foundation. The right of supervision by the United Kingdom was retained and even as late as 1953 the regulation of native affairs was not included in the domain of self-government! In 1959 the then Prime Minister of Southern Rhodesia, Sir Edgar Whitehead, said that ' neither the Federation nor Southern Rhodesia are fully self-governing." 42 S.R.I.A.D. eol. 3043, quoted in Palley, op. cit. note 2 above, at 215.

6 Rhodesia and Nyasaland (Federation) Bill 1953, 1 \& 2 Elisabeth II c. 30; Federation of Rhodesia and Nyasaland (Constitution) Order in Council 1953, S.I. 1953, No. 1199. It is significant that these constitutional changes did not take the opinion of the blacks into aceount and, for this reason, were discussed in 1953 by the 4th Committee of the General Assembly.

6 Rhodesia and Nyasaland Act 1963, 11 \& 12 Elisabeth II, c. 34; Federation of Rhodesia and Nyasaland Order in Council 1963 S.I. 1963, No. 1635. 
independence from the United Kingdom. Britain, as an enlightened Power and as a representative of the Commonwealth, refused to grant independence until there were firm guarantees of genuine majority rule within the country. As Prime Minister Wilson put it, his government had "... a solemn duty to be satisfied that before granting independence it would be acceptable to the people of the country as a whole." ?

The present organization of government within Rhodesia reflects a highly discriminatory restrictiveness in participation rather than the widest possible sharing. The franchise system, which was carried in amended form into the 1961 Constitution, assures the 6\% white population dominance in every aspect of internal public order. ${ }^{8}$ The proclaimed goal of the white settler elite is to maintain this system of domination. ${ }^{9}$ By the beginning of this decade, white intransigeance had forced the two major nationalist groupings into patterns of counter-racism. In the current context of Africa in particular, and the entire third world in general, the intensification of this conflict could only increase the critical threat in the situation.

The British conditions for granting independence to Rhodesia have been supported, and indeed shaped to a great extent, by the demands of the international community as expressed in its most representative organs. The problem of internal order within Rhodesia has, in varying forms, been before United Nations organs since 1962, when the issue came before the General Assembly. ${ }^{10}$ In October, 1965, the General Assembly resolved, by a vote of 107 to 2, to condemn any attempt by the white Rhodesian authorities illegally to seize independence, and declared that the perpetuation of minority rule in Southern Rhodesia would be incompatible with the principle of equal rights and self-determination expressed in the U.N. Charter. ${ }^{11}$ On November 5, 1965, the Assembly

\footnotetext{
7 Statement to Parliament, Nov. 3, 1964, 701 Parl. Debates 67 (5th Series). This was not a partisan position; on July 21, 1961, the then Secretary of State for Commonwealth Relations, Mr. Duncan Sandys, said in the House of Commons: "the British Government would not feel able to give up its reserve powers unless there was a significant alteration of the franchise and a substantial increase in African representation in the Legislature." 644 Parl. Debates, col. 171.

8 See Southern Rhodesia Constitution, Part II-Detailed Provisions, Appendix 1 at 27 ff., and see also $i b i d$. at 12. Cmnd. 1400 (1961).

- Despite numerous statements of benevolence and expressions of genuine commitment to effective democracy, it is quite difficult to avoid concluding that the unilateral declaration of independence was undertaken by the white Rhodesian minority precisely in order to avoid realization of the most fundamental tenet of democracythe effective sharing of power. We note, in this respect, the following statements of Prime Minister Ian Smith, the last of which was delivered in December, 1066: "I cannot in all honesty claim that I am an advocate of majority rule." "Wo will never negotiate with Britain while Mr. Wilson is in his present position because he is waiting for us to reach the position of one man, one vote and this will not happen in my lifetime or Mr. Wilson's lifetime." Quoted by Congressman Rosenthal of Now York, Cong. Rec., Feb. 9, 1967, H 1246.

10 General Assembly Res. 1747 (XVI); 1760 (XVII).

11 Res. 2012 (XX), Oct. 12, 1965; 60 A.J.I.I. 921 (1966).
} 
Noting with grave concern the manifest intention of the present authorities in Southern Rhodesia to proclaim independence unilaterally, which would continue the denial to the African majority of their fundamental rights to freedom and independence,

demanded that independence neither be sought nor accorded on terms other than those conforming to the Charter, the Universal Declaration of Human Rights and Resolution 1514 (XV). The Assembly ealled the matter to the attention of the Security Council as a situation threatening international peace and security. ${ }^{12}$ In spite of these resolutions, the white regime of Prime Minister Ian Smith unilaterally declared Southern Rhodesia independent on November $11,1965 . .^{13}$ On the same day the General Assembly condemned "the unilateral declaration of independence made by the racialist minority in Southern Rhodesia" and called the situation to the attention of the Security Council. ${ }^{14}$ The Assembly's action was paralleled on the following day by the Council. It condemned "the usurpation of power by a racist settler minority" and regarded "the declaration of independence by it as having no legal validity." It called upon all states not to recognize the illegal authority and

... to refrain from any action which would assist and encourage the illegal regime and, in particular, to desist from providing it with arms, equipment and military material, and to do their utmost in order to break all economic relations with Southern Rhodesia, including an embargo on oil and petroleum products.

The Council's actions were based on the premise that the continuation of the situation precipitated by the unilateral declaration of independence would constitute a threat to the peace within the meaning of the Charter. ${ }^{15}$

Attempts to break the oil embargo, in early April of 1966, moved the Security Council to decide that the situation constituted a threat to the peace, to call upon the Portuguese Government not to facilitate the transshipment of oil to Rhodesia, and to authorize the United Kingdom to use force, if necessary, to prevent the oil from reaching Beira, Mozambique, whence it could be transshipped by pipeline to Rhodesia. ${ }^{18}$ The Security Council consolidated and retooled its prior decisions in regard to Rhodesia in December, 1966. At that time it decided again that the situation in Rhodesia constituted a threat to the peace and initiated mandatory economic sanctions. ${ }^{17}$

It is, as yet, impossible to determine the effects which have been generated by the United Nations measures. Reliable statisties from within Rhodesia are not available. The sanctions have obviously taken a toll, but there is

12 Res. 2022 (XX), Nov. 5, 1965; 60 A.J.I.L. 922 (1966).

13 For the text of the Declaration, see 5 Int. Legal Materials 230-231 (1966).

14 Res. 2024 ( $X X$ ), Nov. 11, 1965; 60 A.J.I.L. 924 (1966).

16 Res. 217 (1965), Nov. 20, 1965; 60 A.J.IJ. 924 (1966).

26 Res. 221 (1966), April 9, 1966; 60 A.J.I.I. 925 (1966).

17 Res. 232 (1966), Dee. 16, 1966; 61 A.J.I.I. 654 (1967). 
little indication that they have affected elite perspectives. ${ }^{18}$ The Smith regime, representative of, at most, $6 \%$ of the population, continues to exercise effective control and pursue its questioned practices within Rhodesia. Internal public order has taken on an increasingly authoritarian and racist character, ${ }^{10}$ bearing out post hoc the worst fears expressed in the United Nations since 1962.

18 For a recent report, see Fellows, "Rhodesia Regime is Standing Firm," Now York Times, July 23, 1967, p. 14, col. 3. For a more general consideration, seo Galtung, "On the Effects of International Economic Sanctions, with Examples from the Case of Rhodesia," 19 World Politics 2 (1967); and Hoffman, "The Functions of Eeonomic Sanctions: A Comparative Analysis," 1967 J. Peace Research 140.

19 A detailed survey of Rhodesian enactments, as reported in the Western press, is beyond the scope of this article. See, generally, New York Times, Jan. 17, 1965, p. 3, col. 2; Mrareh 23, p. 14, col. 6; April 13, p. 8, col. 7; May 27, p. 6, col. 7; May 28, p. 2, col. 5; MIay 29, p. 8, col. 8; June 2, p. 6, col. 1; July 15, p. 19, col. 8; Oct. 24, p. 7, col. 1; Oct. 28, p. 1, col. 5; Nor. 6, p. 1, col. 6; Nor. 7, p. 1, col. 2; Nov. 12, p. 1, col. 8; Nov. 17, p. 1, col. 5; Nov. 19, p. 1, col. 5; Nov. 23, p. 1, col. 1 . See also Special Committee on the Situation with regard to the Implementation of the Deciaration on the Granting of Independence to Colonial Countries and Peoplo (1965) (A/5800/Rev. 1; A/6000/Rev. 1). For more detailed and even more dis. quieting surveys, see Leys, "The Growth of Police Powers and the 1959 Emergencies," in Leys and Pratt, A New Deal in Central Africa 131 (1960); Hasson, "Rhodesin-A Police State?" 22 The World Today 181 (1966).

An accurate grasp of the effects of the Rhodesian system upon the majority of the population can only be gained by relation of legislation to contest: ". . . a misleading impression might be obtained from superficial study of Southern Rhodesia legislation, which largely avoids reference to race. . . " Palley, op. cit. note 2 above, at vii. Thus, for example, the constitutional system of enfranclisement, based largoly on wealth criteria, can only be understood in light of the Land Apportionment Act of 1943, under which half of the best land was allocated for white use, i.e., for loss than six percent of the population. Industry is controlled by the whites and tho African worker receives one-twelfth the wage which a European recoives for tho same work. Keatley, The Politics of Partnership (1963). Application of the Preventive Detention Act of 1959, the Vagraney Act and the notorious Law and Order (Maintenance) Act of 1960 have had enormously deprivatory effects upon the black population in almost all sectors of internal public order. Perhaps the most significant indicator of the increasing authoritarian character of the Rhodegian regime has been the effective diminution of the power of the courts, particularly in view of their supervisory rôle in regard to human rights matters, as envisaged in the Constitution of 1961. In Central African Examiner (Prt) Ltd. v. Howman and Others NN.O., the earliest test of the legality of the rebel regime, counsel for one of the government ministries warned the court that "certain dire consequences might overtake the court if it 'took sides' in what amounted to a political strugglo between British and Rhodesian governments"; the court in that ease refused to be intimidated. 1966(2) S.A. 7. (R.) at 14, quoted in Palley, "The Judicial Process: ర.D.I. and the Southern Rhodesian Judiciary," 30 Modern Law Review 263, 269, 270 (1967). But in the recent cases of Madzimbamuto v. Lardner-Burke N.O. and Others, and Baron v. Ayre N.O. and Others, Judgment No. GD/CIV/23/66, discussed in Palley, op. cit. passim, the Rhodesian court, avoiding direct rulings on the legitimacy of the local regime, upheld the lawfulness of the Emergency Powers (Mrintenance of Law and Order) Regulations in regard to the detention of opponents of the authorities, despite the fact that such measures would probably have been materially unlawful in the pre-J.D.I. period. For a comprehensive critique of the decision, seo Welsh, "The Constitutional Case in Southern Rhodesia," 83 Law Quarterly Reviow 64 (1967). 
One of the few heartening aspects of the Rhodesian affair has been the extent to which international law has been invoked by both public and private opinion leaders and appraisers in support of their positions. ${ }^{20}$ Such invocation is a modest index of the potential effective power which global elites perceive in the symbols of international authority, and could pro futuro strengthen and extend the authority of international law. If, however, international law is to develop in patterns consonant with the needs of a world public order of human dignity, it is vital that all such public invocations be subjected to critical appraisal. Though a comprehensive treatment of the many knotty legal problems of the Rhodesian ase must be beyond the scope of this inquiry, it may be possible to place in appropriate perspective certain arguments against the lawfulness of the United Nations' action which touch upon basic constitutive competences and policies and whose importance extends much beyond the particular case.

The principal arguments which have been made against the lawfulness of the United Nations' action, though quite allusive and diffuse in most of their formulations, may be generalized as relating, first, to the substantive merits of the Security Council's finding of "a threat to the peace" in the Rhodesian situation and, secondly, to the conformity of the Security Council's action to certain basic constitutive policies of the United Nations. We propose to examine each of these two sets of arguments seriatim.

The basie substantive argument which has been lodged against the legality of the United Nations' Rhodesian action is that the activities of the white regime in Rhodesia cannot be appropriately characterized as constituting "a threat to the peace" within the meaning of the Charter. Hence, no matter how reprehensible white Rhodesian behavior may be, the basic contingency for the United Nations' measures is absent. Three contentions have been adduced in support of this argument: that the activities of the Rhodesian authorities contain no element of aggression ;

20 English criticism of the Security Council's action is presented and ably appraised in Higgins, "International Law, Rhodesia and the U.N.," 23 The World Today 94 (1967); among the American appraisals which have treated the matter in scholarly firlion, see Goldberg, "International Law in the United Nations," 1966 Proceedings, Ameriean Association of Law Schools, Pt. II, pp. 86, 91; Center for International Studies Policy Paper: Studies in the Theory and Structure of Peaceful Change: Poliey Paper on the Legality of Mandatory Sanctions by the United Nations :1gainst Rhodesia (1967, Franck and Sohn); Rabinowitz, "U.N. Application of Selective, Mandatory Sanctions Against Rhodesia: A Brief Iregal and Political Analysis," 7 Va. J. Int. Law 147 (1967); Fenwiek, "When is There a Threat to Peace?-Rhouesia," 61 A.T.I.L. 661 (1967); Mrarshall, Crisis over Rhodesia (1967). On April 13, 1967, Representative Ashbrook submitted a list of over 45 American Hemspapers which "hare seen fit to eriticize either the stand of the United States or the root of the problem, the mandatory United Nations sanctions." Cong. Rec., House, April 12, 1967, H 4009.

21 Thus, Representative Selden of Alabama: "But what international crime has Rhodesia committed Whose borders has Rhodesia invaded? What section of the 
that the activities of such authorities are wholly lawful under generally accepted international law; ${ }^{22}$ and that, in any case, all such activities transpire within the geographic bounds of Rhodesia. ${ }^{23}$ A careful appraisal of the relevant policies and of the facts of the case will, however, indicate that the Charter provisions have been misunderstood and that, in the absence of an appropriate understanding of the relevant basic policies, the factual elements have not been properly appreciated.

For the better securing of the most fundamental Charter purpose of maintaining "international peace and security," the framers of the United Nations Charter deliberately conferred upon the Security Council, in the provisions of Chapter VII, a very broad competence both to "determine the existence of any threat to the peace, breach of the peace, or act of aggression" and to decide upon what measures should be taken to "maintain or restore international peace and security." 24 Thus, the Conference Committee which drafted these provisions reported, in answer

charter of the United Nations has this small African nation violated On what basis does Great Britain argue that Rhodesia has become a threat to the peaceq" Cong. Rec., House, April 12, 1967, 표 4029.

On the same day, Representative Gurney of Florida asked rhetorically: "Whose peace is Rhodesia breaching besides Harold Wilson's?" Ibid., at H 4035 . See also the remarks of Congressman Bray of Indiana, ibid., at 4031. See also Kilpatrick, "Rhodesia and U.N. Charter," The Plain Dealer, Jan. 5, 1967; editorial in the Washington Post, Dee. 9, 1966, p. A 20, col. 2; letter to the Washington Post, entitled "Acheson on Rhodesia," Dec. 11, 1966, p. E 6, cols. 5-6.

22 Acheson, loc. cit. note 21 above. The Washington Post, speaking editorially, had characterized the acts of the white minority as "transgressions." Former Secre. tary of State Acheson responded: "But you bother me when Jou speak of "tho white minority's transgressions.' Transgressions against what ? What international obligations have they violated?" On April 12, 1967, Congressman Bray of Indiana asked on the floor of the House: "Just what has Rhodesia done? It has not supported a worldwide conspiracy of espionage and subversion. Its armies are not poised for an attack on its neighbors. It has not given support to or encouraged guerrilla warfare in Africa or anywhere else. It has threatened no one, and wants nothing more than acceptance into the community of nations as an independent state, ready and willing to live in peace and honor its international obligations." Cong. Rec., House, April 12, 1967, 且 4031 .

23 See the remarks of Congressman Selden, 7oc. cit. note 21 above. "The white minority's transgressions have occurred within the boundaries of one country . .."; the Washington Post, loc. cit. note 21 above; on Dec. 14, 1966, the Washington Post returned to this point: "they (sanctions) amount to interference in the domestic affairs of another country merely because of the form of government practiced there." ". . . whatever the Rhodesians have done has been wholly within their own country ..." Acheson, loc. cit. note 21 above.

24 Art. 24(1) of the Charter provides: "In order to ensure prompt and effective action by the United Nations, its Members confer on the Security Council primary responsibility for the maintenance of international peace and security, and agreo that in carrying out its duties under this responsibility the Security Council acts on their behalf." Art. 39, which introduces Chapter VII of the Charter-Action with Respect to Threats to the Peace, Breaches of the Peace, and Acts of Aggressionprovides, in its entirety, that: "The Security Council shall determine the existence of any threat to the peace, breach of the peace, or act of aggression and shall make recommendations, or decide what measures shall be taken in accordance with Articles 41 and 42 , to maintain or restore international peace and security." 
to proposed amendments for advance specification, that it had been decided "to leave to the Council the entire decision as to what constitutes a threat to the peace, a breach of the peace, or an act of aggression," 25 and a comparable discretion in the choice of measures for maintaining or restoring peace and security was written into the very words of the relevant sections of Chapter VII. ${ }^{2 B}$

The thought which moved the framers, in rejecting all proposed definitions of the key terms "threat to the peace," "breach of the peace" and "act of aggression," was that, for effective discharge of the very difficult and delicate task being imposed upon it, the Security Council should be accorded a large freedom to make ad hoc determinations after a full, contextual examination of the peculiar features of each specific situation of threat or coercion. The facts which might in the future endanger international peace and security could be infinitely various, with the significance of any particular feature of the context being a function of many other features, and the measures which might best promote the establishment and maintenance of peace and security in any specific situation could require careful tailoring to fit the unique requirements of that situation. ${ }^{27}$ The course of subsequent events has clearly demonstrated the wisdom of this view, and few voices have been heard to suggest that the broad discretion of the Security Council could rationally be curtailed.

Similarly, it was clearly within the expectations of both the framers and the general community that action by the Security Council might have to be anticipatory and was not required to await the full consummation of disaster. Thus, the competence accorded to the Council in Article 39 relates not merely to perfected "breaches of the peace" and "acts of aggression" but explicitly extends also to the prevention and removal of

2512 U.N.C.I.O. Does. 505.

2B Thus, Art. 40 authorizes the Council, "in order to prevent an aggravation of the situation," to "call upon the parties concerned to comply with such provisional measures as it deems necessary or desirable." Art. 41 authorizes the Council to take "measures not inrolving the use of armed force to give effect to its decisions," and Art. 42 provides that "Should the Security Council consider that measures provided for in Article 41 would be inadequate or have proved to be inadequate, it may take such action by air, sea, or land forces as may be necessary to maintain or restore international pexce and security." Although Art. 42 does not limit the coercive modalities to which the Security Council may resort, it specifically cites "demonstrations" and "blockades and other operations" as lawful.

27 Thus, in the Greek frontier incidents of 1947, the Council resolved that supporting armed bands in erossing into another state should be characterized " as a threat to the peace within the meaning of the Charter of the United Nations." But the Council qualified this communication as being only a point of view and reserved for itself the necessity of determining whether the future occurrence of such a case would, in fact, constitute a threat to the peace. Security Conncil, 2nd Year, Ofincial Records, No. 66, 170th meeting, pp. 1604, 1612. For a general evaluation, see 2 Repertory of Practice of United Nations Organs 354-356 (1955). Comparable reticence to limit itself to a rigid position in the future characterized the Council's response to Syrian-Israeli clashes in January, 1956. 1 Repertory of Practice of United Nations Organs, Supp., Vol. 1, p. 330 (1958). 
"threats to the peace." 28 Even the inherited customary international law of self-defense, which authorizes states confronted with an imminent threat to their territorial integrity or political independence to employ the military instrument, does not require target states to remain immobilized, in the posture of sitting ducks, for a first blow. ${ }^{29}$ It could not be expected that basic constitutional policies would impose more rigid requirements upon the organized general community as a prerequisite to the employment of a wide range of sanctioning measures. On the contrary, the potentialities that inhere in a "policy of prevention" and of appropriate sanctioning measures to secure such a policy have come to be widely accepted. ${ }^{30}$

It may require emphasis, further, that, as the legislative history of Article 39 anticipates and subsequent practice confirms, the Security Council is authorized to find a "threat to the peace" in a specific situation without an allocation of blame or fault to any of the parties. The finding of a "threat to the peace" is a factual determination only, though an indispensable procedure for establishing the authoritative base for sanctioning measures. When peace is threatened, the function of the United Nations is to restore peace and its necessary supporting conditions as quickly and as economically as possible. In this age of instant Armageddon, small solace could be gained from a realization that civilization was destroyed for "good" and not "evil" reasons. Fiat justitia pereat mundus is not the principal underpinning of Article 39. The determinations of "threats to the peace" which have been made in the past have related to highly diversified fact complexes, but have, significantly, not hitherto sought to impute responsibility to a particular state. The invariable formulation has been that a "situation" constitutes a threat to the peace. ${ }^{31}$ Commenting upon identical language in a related provision of the Charter, the International Court observed that the Charter

.. . speak(s) of "situations" as well as disputes, and it must lie within the power of the Security Council to police a situation even though it does not resort to enforcement action against a State. ${ }^{.2}$

28 Attention should also be given to the two terms, employed in Art. 39, signifying the dual objectives of the Council, operating under Chap. VII: measures may bo taken "to maintain or restore. ..." While "restore" clearly rofers to romodial action subsequent to a perfected breach of the peace, "maintain" refers to pro. liminary action aimed at removing or forestalling an imminent threat to the peace which has not yet materialized into a "breach."

$29 \mathrm{Cf}$. MreDougal and Feliciano, Law and Minimum World Public Order 192-193, footnote 164 (1961).

30 See Hammarskjöld, "The United Nations and Preventive Action," Press Conference, Feb. 27, 1956, in Hammarskjöld, Servant of Peace 133-135 (1962).

31 This past practice is not, of course, indicative of a constitutional incapacity on the part of the Security Council to identify the party responsible for breaching the peace or creating a threat to the peace. The point to be emphasized is that the Council, in exercising its powers under Chap. VII, is concerned primarily with maintaining or restoring the peace and only secondarily with determining who is responsible for the erisis.

32 Certain Expenses of the United Nations (Article 17, paragraph 2 of the Charter), [1962] I.C.J. Rep. 151, 167; 56 A.J.I.I. 1053 (1962). 
Indeed, in a critical moment when humanity might rapidly approach the point of nuelear immolation, the question of who was responsible would be neither a relevant nor an intelligent consideration for those charged with avoiding irretrievable disaster.

It is not intended, however, to suggest that the broad competence accorded the Security Council to make determinations of "threats to the peace" is absolute, without limit or safeguard. The appropriate exercise of such competence must of course require an evaluation of any alleged "threat" in its relevant context and the relation of such challenged activity to the major Charter purpose of maintaining international peace and security; ${ }^{33}$ and the Charter, like other constitutions which confer broad competences for action, establishes certain important procedural safeguards against arbitrary and spurious decisions. The expectations of the general community about the requirements and consequences of an appropriate decision by the Security Council are indicated in a dietum of the International Court of Justice in the Certain Expenses case:

The primary place aseribed to international peace and security is natural, since the fulfilment of the other purposes will be dependent upon the attainment of that basic condition. These purposes are broad indeed, but neither they nor the powers conferred to effectuate them are unlimited. Save as they have entrusted the Organization with the attainment of these common ends, the Member States retain their freedom of action. But when the Organization takes action which warrants the assertion that it was appropriate for the fulfilment of one of the stated purposes of the United Nations, the presumption is that such action is not ultra vires the Organization. ${ }^{34}$

The procedural safeguards established by the Charter are incorporated in the roting procedures prescribed for the Security Council, which require the concurring rotes of the permanent members and a special majority of all members. ${ }^{35}$ The probabilities of arbitrary or spurious decisions escaping these procedures would not appear great. ${ }^{38}$

33 Thus, Art. 24 of the Charter, after conferring on the Seeurity Council "primary responsibility for the maintenance of international peace and security," continues in its second paragraph: "In discharging these duties the Security Council shall act in accordance with the Purposes and Principles of the Onited Nations. The snecific potrers granted to the Security Council for the discharge of these duties "re laid domn in Chapters VI, VII, VIII and XII."

34 [1962] I.C.J. Rep. 151, 168.

35 Charter, Art. 27(3). Portugal and South Africa have criticized the Security Council's decision on the ground that all permanent members did not affirmatively concur (the U.S.S.R. and France abstained). A number of other commentators have challenged the legality of the decision in this respect. Any lingering questions regarding the lawfulness of Couneil practice in this regard are dispelled in Stavropoulos, "The Practice of Voluntary Abstentions by Permanent Members of the Seeurity Council under Article 27, Paragraph 3, of the Charter of the United Nations," 61 A.J.I.L. 737 (1967). See also Higgins: " . . . as early as 1947 . . . the Security Council was required to decide whether the expression 'including the concurring votes of the Permanent Members' meant their affirmative votes: or whether abstention, though not casting a negative rote, could be taken to mean 'coneurrence'. It was then decided, and has since been confirmed on some 107 separate occasions that I am aware of, that the Permanent Members shall be deemed 'to concur' if they 
The important criticisms of the Rhodesian Resolution, as we have noted above, relate more to the relevant substantive criteria than to the procedures by which the decision was taken. Indeed, it would not appear that any plausible question could be raised about the conformity of the decision to the stipulated Charter procedures. For demonstrating that the decision is, in its substantive merits, no less in accord with the basic policies established by the Charter, the most economic mode of exposition will be by way of explicit answer to each of the specific contentions which have been urged against the lawfulness of the decision.

The first argument against the lawfulness of the decision is that the actions of the white Rhodesians contain no element of aggression: ". . . whatever the Rhodesians have done has been wholly within their own country and contains no element of aggression." 87 Article 39 does not, however, require "aggression" as a constituent element of a threat to the major inclusive concerm. ${ }^{38}$ This is not to imply that an act of aggression cannot constitute or precipitate a threat to, or breach of, international peace. The point is that it is not necessary, in order to support a finding of a threat to the peace, that some act of overt aggression should have actually been committed. ${ }^{30}$ The aggression argument is thus irrelevant to the determination of a "threat" under Article 39 of the Charter.

Yet, it must be added that Rhodesian action does involve elements of aggression in the most comprehensive, relevant sense. The seizure of control of territory which all states of the world recognize to be under the sovereignty of the United Kingdom, accomplished contrary to the desires both of the United Kingdom and the indigenous population of that territory, could be appropriately characterized as an act of aggression against the United Kingdom. Moreover, the promulgation and application of policies of racism in a context as volatile as that of Rhodesia and

abstain. If they wish to prevent the passage of a resolution, they may do so by casting a negative vote." Higgins, "International Law, Rhodesia and the U.N.," 23 The World Today 94, 97 (1967).

86 It is for this reason that, in an effort to establish the utmost finality obtainablo through procedural criteria, the Charter makes no provision for appeal from a decision by the Security Council and prescribes in Article 25 that all Members are obligated to accept and carry out the decisions of the Council.

37 Acheson, The Washington Post, loc. cit. note 21 above. For comparable statements, see note 19 above.

38 At the U.N. Conference on International Organization it was suggested, in rogard to Art. I(I), that the terms "other breaches of the peace" following mention of "aggression" be struck as redundant. The suggestion was rejected: ". . . thoro may be breaches of the peace other than those qualified by present connotation as aggression and the subcommittee decided to keep "other breaches of the peace" as an all-inclusive term which implies the use of any means of coercion or undue external influence..." U.N.C.I.O. Doc. 723, I/1/A/19, p. 8, Report of the Rapporteur, Subcommittee $1 / a$ to Committee $I / 1$.

39 Thus a leading commentator criticizes the Charter formulation for redundancy. 'The express mentioning of 'acts of aggression' is superfluous since these acts aro incladed in the concept, 'breaches of the peace'." Kelsen, The Law of the United Nations 14 (1950). 
South Central Africa must give rise to expectations of violence and constitute, if not aggression of the classic type, at least the creation of circumstances under which states have been customarily regarded as justified in unilaterally resorting to the coercive strategies of humanitarian intervention. ${ }^{* 0}$ Hence, even if aggression were a constituent element of a threat to the peace, which as demonstrated it is not, the actions of the Rhodesian elites could supply the contingency for United Nations action.

The second argument against the lawfulness of the Security Council decision is that the activities of the Rhodesian elites have been entirely in accord with international law.11 One compelling answer is that the Charter does not require a violation of international law in any sense other than the constitution of a threat to the peace. In point of fact, however, the list of indictments of Rhodesian transgressions against international law is alarmingly long. As far as conventional international law is concerned, the Rhodesian authorities have repudiated a number of Security Council decisions, ${ }^{42}$ which, under Article 25 of the Charter, are binding upon all Member States ${ }^{43}$ and which, according to Article 2(6), may be applied to non-members "so far as may be necessary for the maintenance of international peace and security." 44 They have also repudiated the human rights provisions of the Charter, ${ }^{45}$ as authori-

106 Moore, International Law Digest 347-367 (1906); Lauterpacht, International Law and Human Rights $120 \mathrm{ff}$. (1950); Murty, Propaganda and World Public Order: The Legal Regulation of the Ideological Instrument of Coercion 83, footnote 16 (1968).

"The International Law of the Future," 399 International Conciliation 268; 38 A.J.I.I. Supp. 55 (1944), provides: "Each state has a legal duty to see that conditions prevailing within its own territory do not menace international peace and order, and to this end it must treat its own population in a way which will not riolate the dietates of humanity and justice or shock the conscience of mankind."

11 It should require no emphasis that the suggestion that the Rhodesian elites are aeting in contravention of basic policies of international law carries no implication that they may be appropriately regarded as a state. The notion that only states may riolate international law is no longer accepted as even a half-truth; and the fact that a rebelling group acts in contravention of the basic policies of international law is but another good reason for denying it the benefits of statehood.

t2 Res. 221 (1966), April 9, 1966; Res. 232 (1966), Dec. 16, 1966, cited notes 16 and 17 above.

43 Art. 25 provides: "The Mrembers of the United Nations agree to accept and carry out the decisions of the Security Council in aceordanee with the present Charter."

14 Eren if it should be assumed, contrary to fact, that Rhodesia is a new state, Art. 2(6) provides: "The Organization shall ensure that states which are not Mrembers of the United Nations act in aceordanee with these principles so far as may be necessary for the maintenance of international peace and security." On the innovative eharacter of the prorision, see Goodrich and Hambro, Charter of the United Nations: Commentary and Documents 108-109 (2d rev. ed., 1949), and, more generally, Kelsen, Peace through Law 38 (1944). Consider, in this regard, the relevance, in converse application, of the I.C.J.'s dictum in the Reparations case, [1949] I.C.J. Rep. 174: ". . . the vast majority of the members of the international community, had the power, in conformity with international law, to bring into being an entity possessing objective international personality, and not merely personality recognized by them alone ..." Ibid. at 185; 43 A.J.I.I. 589 at 598 (1949).

45 See Preamble, Art. 1(2), (3), Art. 13(1) (b), Arts. 55 and 56, Art. 62, Art. 73. 
tatively interpreted by the competent U.N. organs, and the prescriptions of the increasingly authoritative Universal Declaration. ${ }^{46}$ As far as international customary law is concerned, they have violated the more traditional human rights policies in a degree which, as we have noted, would have in the past served to justify "humanitarian intervention" by individual nation states. ${ }^{47}$ It searcely need be added that circumstances which would justify coercive action undertaken unilaterally by one state must surely be regarded as sufficient to justify organized international action. As far as "general principles" are concerned, the Rhodesian elites have violated the principle of good faith by failing to make effective the assurances which they gave the United Kingdom at various times for just treatment of the African population. The act of unilateral declaration of independence and the subsequent internal legislation violated, as will be documented below ${ }^{48}$ the principle of self-determination in relation to the great bulk of the Rhodesian people, as well as British sovereignty. In the most fundamental sense, the assertion of independence at a time and by means which the authoritative organs of the international community had decided would precipitate a threat to the peace of the surrounding region and the world was an act of irresponsibility in violation of the most basic policies of the Charter for the maintenance of international order.

The final argument of the critics of the Security Couneil decision is that, even if the acts of the white Rhodesians are unlawful, they are insulated from international concern by virtue of the fact that they occur only within Rhodesia and affect no one else. This bald contention that the actions of the white Rhodesians occur only within the territorial bounds of Rhodesia is factually incorrect. In the contemporary intensely interdependent world, peoples interact not merely through the modalities of collaborative or combative operations but also through shared subjectivities -not merely through the physical movements of goods and services or exercises with armaments, but also through communications in which they simply take each other into account. The peoples in one territorial community may realistically regard themselves as being affected by activities in another territorial community, though no goods or people cross any boundaries. Much more important than the physical movements are the communications which peoples make to each other. ${ }^{40}$ In the case of Rhodesia, the other peoples of Africa have regarded themselves as affected by the authoritarian and racist policies of the Rhodesian elites. In the context of a world opinion which since World War II has come increasingly to recognize the intimate interdependence of the maintenance of minimum human rights and international peace and security, ${ }^{50}$ it would certainly not be easy to demonstrate to these peoples that their expectations of grievous 46 General Assembly Res. 217 (III), Dec. 10, 1948; 43 A.J.I.I. Supp. 127 (1949). 47 See note 40 above. 48 See below at p. 17.

49 For more comprehensive consideration of this aspect of interaction, seo M[eDougal, Lasswell and Reisman, "The World Constitutive Process of Authoritative Decision," 19 Journal of Legal Education 253, 254 (1967).

50 The intimate nexus between human rights and minimum world order is clearly articulated in Art. 55 of the Charter: "With a view to the creation of conditiong 
injury from the Rhodesian model are ill-founded. It has been too often confirmed that practices of indignity and strife which begin as internal in physical manifestation in a single community quickly and easily spread to other communities and become international.

It may thus be concluded that the criticisms of the Security Council decision about Rhodesia in terms of its substantive merits are quite without merit. The determination of "aggression" is not a necessary contingency to the imposition of sanctions under Article 39, though in fact the activities of the Rhodesian elites would appear to contain elements of aggression. The activities of the Rhodesian elites have not, as alleged, been lawful under international law, but have, to the contrary, been in breach of a variety of fundamental international norms. The ascription of a complete interuality to the Rhodesian aetivities is visibly incorrect and, even if it were correct, could not, as will be demonstrated below, establish an immunity from the application of Article 39.51 The decision of the Security Council would appear, in sum, entirely appropriate in its relation of the specific situation before it to the basic substantive criteria both of the Charter and of customary international law.

\section{II}

The arguments relating to basic constitutive limitations which are alleged to preclude the United Nations from lawfully acting in the Rhodesian case invoke the principle of domestic jurisdiction and the right of self-determination. The activities of the white Rhodesian minority are, it is argued, essentially within their domestic jurisdiction and hence insulated from the appraisal and supervision of authoritative international processes. ${ }^{62}$ The unilateral declaration of independence by the white elites constitutes, it is claimed, an exereise of self-determination; by seeking to suppress this action, the United Nations is, itself, acting against a fundamental postulate of contemporary international law. ${ }^{63}$

of stability and well-being which are necessary for peaceful and friendly relations among nations based on respect for the principle of equal rights and self-determination of peoples, the United Nations shall promote:

a. higher standards of living, full employment, and conditions of economic and social progress and development;

b. solutions of international economie, social, health, and related problems; and international cultural and educational cooperation; and

c. unirersal respeet for, and obserrance of, human rights and fundamental freedoms for all without distinetion as to race, sex, language, or religion." (Italics supplied.)

$\therefore 1$ See below at p. 14 .

52 Thus, the Washington Post, loc. cit. note 21 above, states that "The white minority's transgressions have oceurred within the bonndaries of one country . . ."; see also idem, Dec. 14, 1966, to the same effect; see Acheson, loc. cit. note 21 above. See also Kilpatrick, loc. cit. note 21 above, and the statements of Congressmen cited at notes 20 and 21 .

53 The harshest criticism leveled on this ground has come from the pen of the American columnist, James J. Kilpatrick (loc. cit. note 21 above). Commenting upon a statement by Ambassador Goldberg, Kilpatrick wrote: "c 'The Security Couneil's 
The short and conclusive answer to the argument in terms of domestic jurisdiction is that, once certain activities constitute a threat to international peace and security, they cease to be, if ever they were, "matters essentially within the domestic jurisdiction" of a state. "Still further, even if such activities should be thought by some unspecified criteria to remain within the compass of domestic jurisdiction, the very words of the Charter clause, Article 2(7), which ereated the vague and elusive limitation upon the organization's competence, ${ }^{55}$ explicitly provide in a well-known exception that "this principle [that of domestic jurisdiction] shall not prejudice the application of enforcement measures under Chapter VII." The basic constitutional framework of an inclusive organization whose principal purpose is to maintain international peace and security could scarcely prescribe otherwise: if states were to be permitted to impede the organized community's efforts to rectify situations by claims that activities, however threatening, are immune from inclusive concern because they are within domestic jurisdiction, the principal purpose for which the whole constitutive structure is established and maintained could be easily defeated.

action in imposing mandatory sanctions upon Rhodesia,' said the ambassador, 'does not flout the principle of self-determination.' And this is because the white minority Rhodesian regime is not asserting the right of self-determination. It would appear to the mind of ordinary men, gifted with ordinary powers of reason, that it is immaterial what the white minority Rhodesian regime asserts. The action of the Security Council either flouts, or it does not flout, regardless of any assortion in Salisbury."

54 In this respect, the formal exception, in the final clause of Art. 2(7), to the operation of the principle of domestic jurisdiction is superfluous: if "the Security Council, acting under Chapter VII, decided upon enforcement action, it would bo deciding that the matter threatened international peace and security and thereforo had already gone beyond the limits of domestic jurisdiction." Higgins, The Development of International Law through the Political Organs of the United Nations 87 (1963). Cf. Lauterpacht, International Law and Human Rights 177 (1950): " a matter is no longer essentially within the domestic jurisdiction of a State if it has become a matter of international concern to the extent of becoming an actual or potential danger to the peace of the world."

55 "The words 'domestic jurisdiction' are neither possessed of any intrinsic or absolute meaning nor are they self-defining. Neither official pronouncement nor practice of states has ever given them a very preeise meaning for any purpose, much less of relevance to rational action about human rights in the contemporary world. Introduced into the Covenant of the League of Nations on the suggestion of American statesmen in the vain hope of appeasing isolationist sentiment, this 'mischievous phrase' has, in the apt description of a distinguished critic [Brierly], become a 'new catchword' or verbal 'idol' to serve the same old function that words like 'sovereignty,' 'independence' and 'state equality' have so long served. That function is much too often to put a stop to thought, to summarize conclusions reached on unexpressed or perhaps even unexamined or unconscious grounds, and to assert arbitrary refusal to negotiate or eooperate on problems regarded by other states as of common concern." MreDougal and Leighton, "The Rights of Man in the World Community: Constitutional Illusions Versus Rational Action," 59 Yale Law J. 60, 80-81 (1949) ; Brierly, "Matters of Domestic Jurisdiction," 6 Brit. Yr. Bk. Int. Law 8 (1925); Bentwich, "The Limits of the Domestic Jurisdiction of the State," 31 Grotius Society Transactions 59 (1945). 
The invocation of the principle of domestic jurisdiction in the Rhodesian context is, further, ultimately founded on a serious misunderstanding of the contemporary relation between human rights and matters of "international concern." The point is that, even in the absence of a finding of a threat to the peace, the United Nations could have acquired a considerable competence with respect to Rhodesia because of the systematic suppression of human rights practiced there. ${ }^{56}$ The concept of domestic jurisdiction in international law has never been impermeable. ${ }^{57}$ Actions occurring within the territorial bounds of one state with palpable deprivatory effects upon others have always been subject to claim and decision on the international plane. There has searcely ever been a case of major proportions in which the principle of domestic jurisdiction has not been invoked; where transnational effects have been precipitated, the principle has rarely barred effective accommodations in accord with inclusive interest. Hence, domestic jurisdiction means little more than a general community concession of primary, but not exclusive, competence over matters arising and intimately concerned with aspects of the internal public order of states. Where such acts precipitate major inclusive deprivations, jurisdiction is internationalized and inclusive concern and measures become permissible.

The important provision in Article 2(7) of the Charter "8_that "this principle shall not prejudice the application of enforcement measures under Chapter VII" - is only the most urgent example of the permeability of domestic jurisdiction to international supervision. Any matter originating in one state with deprivatory effects going beyond its borders may become a matter of international conceru. The peoples of the world may regard it as a matter of international concern and their perspectives may, from the standpoint of an observer, be realistic. Recent decades have witnessed tremendous changes in the perception by peoples of their interdependences with respect to human rights and in their efforts to clarify and establish appropriate prescriptions and structures to take these interdependences into account. Under Articles 55 and 56 of the Charter, it is made basic constitutive preseription that the minimum conditions of a dignified human existence are to be realized and maintained by Member States by

666". . human rights and freedoms, having become the subject of a solemn international obligation and of one of the fundamental purposes of the Charter, are no longer a matter which is essentially within the domestic jurisdiction of the Members of the United Nations . . " Lauterpacht, International Law and Human Rights 178 (1950).

6z Tunis-Moroceo Nationality Decrees, P.C.I.J., Series B, No. 4 (1923).

58 Art. 2(7) in conjunction with Art. 39 may be compared, in this regard, with its counterpart provision in the Corenant of the League of Nations. According to Art. 15(8) of the Corenant, as authoritatively interpreted by the Permanent Court of International Justice, a determination of domestic jurisdiction, once made, would hare precluded an international organization from participating in the resolution of a dispute, even if the dispute constituted an inclusive threat to the peace. The Pact of Bogota suffers from a similar rigidity, though it is redeemed by recourse available to the Security Council in instances in which regional processes prove incapable of functioning. 
"joint and separate action in cooperation with the Organization." so The Universal Declaration of Human Rights ${ }^{\circ 0}$ has recommended to all peoples the enhanced protection of all the more fundamental rights of a free society and is becoming increasingly more authoritative through widespread acceptance in decision. Many different conventions for the protection of different particular rights have been drafted under United Nations auspices and have achieved varying degrees of promulgation and acceptance. ${ }^{01}$ The movement toward a system of enforcement by individual petition, ${ }^{62}$ though as yet in but primitive form, is only further corroboration of important progress in internationalizing concern for human rights.

Thus, even were Rhodesia a state for United Nations purposes, and even were there no finding of a threat to the peace of major international proportions, the claim of "domestic jurisdiction" could not be involsed effectively to insulate the systematic deprivation of human rights in Rhodesia from the scrutiny and rebuke of "international concern." वs

50 It is particularly significant that Art. 55 expressly notes the necessary nexus between the maintenance of human rights and "the creation of conditions of stability and well-being which are necessary for peaceful and friendly relations among nations. ..." For further discussion, see $\mathrm{M}$ CDougal and Leighton, loo. cit. note 55 above, and Lauterpacht, op. cit. note 56 above: "the correlation betweon peace and observance of fundamental human rights is now a generally recognized fact. The circumstance that the legal duty to respect fundamental human rights has become part and parcel of the new international system upon which poace depends, adds emphasis to that intimate connexion." Ibid. at 186.

60 General Assembly Res. 217 (III), Dec. 10, 1948, cited note 46 above.

61 Declaration on the Granting of Independence to Colonial Countries and Pooples, General Assembly Res. 1514 (XV), Dee. 14, 1960; Declaration on the Elimination of All Forms of Racial Discrimination, General Assembly Res. 1904 (XVIII), Nov. 20, 1963; 58 A.J.I.L. 1081 (1964); International Covenant on Civil and Political Rights, General Assembly Res. 2200 (XXI), Dec. 16, 1966, 61 A.J.I.工. 870 (1967). Of particular relevance is the Convention on the Elimination of Racial Discrimination of 1965, 60 A.J.I.I. 650 (1966), which now has more than sixty signatures and almost a scoro of ratifications.

62 The initial setback in 1947, when the Commission on Human Rights soverely limited the broad competence granted under Charter Art. 68 and reiterated in a Commission resolution in 1948, has not barred positive action: Report of 1st Soss. of Commission on Human Rights, E/259, pars. 21-23; Economic and Social Council Res. 75 (V). Fror documentation of the process by which this bar has been steadily eroded, see Statement by Dr. Egon Schwelb to the Conference of UNA-USA, New York, April, 1967. One recent example of erosion is in the Optional Protocol to the Proposed Covenant on Civil and Political Rights, 61 A.J.I.L. 887 (1967); 4 U.N. Monthly Chronicle 69 (1967).

63 Some critics have urged that there is a certain hypocrisy in the selectivity of the application of human rights policies. Human rights norms, it is argued, are sought to be applied in one seetor of the world, yet violations are apparently ignored in others. A fundamental policy of democratic public order is, indeed, equality in the application of basic policies in comparable instances. Ideally, human rights should be vindicated, at once, everywhere-most especially when their violation creates threats to international peace. In a decentralized world arena, however, in which power is dispersed in many different ways, the application and fulfillment of basic human rights policies must be guided by the opportunities presented, or exigoncies imposed, by context and by the potentialities of control. Rhodesia, from this perspective, is more than an opportunity. Failure to act there might not merely fail to 
It may, however, be noted in further demonstration of the irrelevance of "domestic jurisdiction" that the benefits of this allegedly saving limitation inhere only to states. ${ }^{64}$ The United Nations and its Members have decided, through authorized procedures, not to recognize the regime in Rhodesia as a state until it accommodates itself to the internal and external demands for a genuine sharing of power, majority rule, and conformity to the basic human rights principles of international law. The Security Council decided that a unilateral declaration of independence without prior arrangement for these vital matters would, in the context of South Central Africa, constitute a threat to the peace. ${ }^{65}$

The recognition of a community as a state for some or all purposes has long been regarded as largely within the discretionary competence of each pre-existing state, and there are no generally accepted criteria to compel a recognition which a state wishes to withhold. Competences which individual states may exereise separately, they may of course exercise jointly. Neither the United Nations as a collective organ nor any state of the world has recognized Rhodesia as a state. ${ }^{66}$ To argue, in spite of these facts, that the white authorities are entitled to the benefit of those international policies aimed at sustaining the political integrity of bona fide state members of the world community is at least modestly incongruous.

The unilateral declaration of independence of November 11, 1965, by the Rhodesian elites was carefully calculated to animate the highly emotive symbols of self-determination. ${ }^{67}$ The right of self-determination is undoubtedly an important feature of contemporary international law, though the exact content of the right, the criteria for its application, and the procedures for a contextual examination of situations in which it is claimed

fulfill contemporary polieies in the inclusive promotion of human rights; it might, furtlier, set back or undermine the whole United Nations program. In the most realistic sense, the impossibility of achieving perfection is scant justification for total inaction.

3. Discussions of the status of Rhodesia have tended to oversimplify the entire problem of state establishment and recognition. In particular, the Smith government bas been anxious to demonstrate its de jure existence by reference to the demands which the organized community has made upon it, including the operation of Article 39 of the Charter, and, at the same time, has insisted that the right to determine its objective existence is an inherent right. Some of the arguments which have been inroked are clearly irrelevant. The Rhodesian Information Office in Washington, D.C., for example, in an undated response to an official statement by Ambassador Goldberg, reprinted in Cong. Rec. Appendix, Feb. 13, 1967, at A 607-609, cited cases of acceptability of Southern Rhodesia in certain organized arenas before Nov. 11, 1965, as purported indications of recognition of its status as a state. Whatever the appropriate indices of recognition, the behavior of other states supposedly indicative of tacit recognition is relevant only after Nov, 11, 1965.

Both Rhodesian authorities and a number of American commentators have sought to derive state status from the facts of effective control. Yet states have never made recognition of statehood contingent upon control alone: they have always applied a series of interrelated criteria requiring appraisal in terms of both authority and control. It is significant that no state has recognized Rhodesia on the basis of these or any other criteria. 65 Res. 217 (1965).

66 See [1949] I.C.J. Rep. 174, 185, cited in note 44 above.

675 Int. Legal Materials 230-231 (1966). 
have, as yet, not been carefully delineated. ${ }^{68}$ The earlier experience with homogeneous ethnic and cultural groups is not wholly relevant, since recent decades have witnessed a noticeable shift in emphasis from "groups" and "peoples" to individual human rights and notions of democracy. In particular, the precise rôle of the United Nations in supervising the conflicting claims of groups for self-determination and the regulation of minority guarantee provisions remain to be successfully determined."0 The Trusteeship Council experience and the Cyprus case, are, however, firm expressions of authority for the proposition that conflicts of this sort are properly of international concern.

Whatever the difficulties which continue to inhere in the clarification of appropriate policies about self-determination, the irrelevance of any such policies for protecting the claims of the Rhodesian elites would seem to be clear. Whether one invokes criteria related to the older notions of homogeneous ethnic and cultural groups or to the newer notions of individual human rights and democracy, and whether one investigates sociological, political, psychological or historical factors, by no stretch of the imagination can the actions and avowed and executed political programs of the white Rhodesian minority be characterized as genuine Rhodesian self-determination. It would be a travesty upon the most basic notion of "self-determination" to speak of it, in regard to a claim of $6 \%$ of a population against $94 \%$ of a population, when the goal of the claim is to gain absolute political control over the majority and to maintain them in a state of secondary and powerless citizenship. It would be completely contrary to the very purposes for which the contemporary right of selfdetermination has been created to employ it to justify the systematic suppression of the human rights of the vast majority of the population for no other reason than to maintain the social, political, and economic superiority of a mere six percent of the occupants of the area.

\section{III}

It must, accordingly, be concluded that the Security Council decision imposing mandatory sanctions in the Rhodesian situation, contrary to the vigorous criticisms which have been asserted of it, makes an entirely appropriate relation of the facts before the Council to all the relevant basic community policies embodied in the United Nations Charter. In terms of substantive merits, the decision realistically recognizes that in the contemporary world, international peace and security and the protection of human rights are inescapably interdependent and that the impact of the flagrant deprivation of the most basic human rights of the great mass of the people of a community cannot possibly stop short within the territorial boundaries in which the physical manifestations of such deprivations first occur. In terms of the constitutive limitations established by the Charter,

68 Eor comprehensive treatment, see Mensah, Self-Determination under United Nations Auspices (Unpublished J.S.D. dissertation, Yalo Law School, 1963).

60 Tbid. at 282-324. 
the fact that the situation in Rhodesia has been authoritatively found to constitute a threat to international peace makes irrelevant all conceptions of "domestic jurisdiction," and the decision of the Council would not constitute an infringement of the domestic jurisdiction, properly conceived, of Rhodesia, even if Rhodesia were a state entitled to the benefit of the domestic jurisdiction doctrine. Similarly, so far from constituting a violation of the right to self-determination of the great mass of the Rhodesian people, the Security Council resolution is but the most recent expression of a general community concern to preserve that right for them.

The present dispositions of effective power about the globe will, of course, make diffeult the immediate securing of the long-term objectives of the United Nations action. Yet with respect to international governmental organizations, as with respect to the men who constitute them, one of the conditions of progress toward major objectives may be that authoritative reach must sometimes exceed effective grasp. 